\title{
Gestures as a Transnational Language through Woodcuts: Celestina's Title Pages ${ }^{1}$
}

\author{
Marta Albalá Pelegrín \\ California State Polytechnic University, Pomona
}

\begin{abstract}
Following the publication of Fadrique de Basilea's Comedia de Calisto y
\end{abstract} Melibea in 1499, Celestina became one of the most profusely illustrated books of the sixteenth century. From the craftsmanship of Fadrique de Basilea's illustrations to other less skillfully crafted editions, such as those of Stanislao Polono (1501), Celestina's woodcuts have lately received a great deal of attention regarding their artistic sources, their interrelation with the text, and their editorial and textual history. ${ }^{2}$ My inquiry draws from these recent studies and aims to further contribute to the understanding of the different iconographic programs, as well as to the contemporary readings that printers and illustrators had of the text. To this end, my analysis will focus on one aspect that has been hardly explored: the study of the body language featured in the title-page woodcuts of its early editions. ${ }^{3}$ This study provides a preliminary approach to how

1.- I would like to express my gratitude to all those who have seen, read, or discussed parts of this article. I am especially thankful to Alicia Miguélez (Postdoc Researcher, Instituto de Estudos Medievais, Faculdade de Ciências Sociais e Humanas, Universidade Nova de Lisboa), who provided me with precious insights and bibliographical notices from her knowledge on gestures during the Middle Ages. My special thanks go also to my mentor and friend Ottavio DiCamillo (Emeritus Professor, The Graduate Center, CUNY), and my dear colleagues and friends Vanessa Pintado (The Hispanic Society of America, Assistant Librarian), and Javier Patiño Loira. Additionally, a 2015 RSCA Research Grant from California State University, Pomona, has allowed me to devote time to this research.

2.- A cluster of works has been devoted in recent years to the study of Celestina's illustrations. Notable contributions include a rich group of studies on Fadrique de Basilea's 1499 woodcuts: Berndt Kelley; Rodríguez-Solás; and Cull. Other scholars have analyzed the printing, publishing and reception history of Celestina through its woodcuts. See, for instance, Abad; Alvar; Carmona Ruiz; Fernández Rivera; and Snow.

3.- My definition of body language relies on the approaches of Garnier, and of Miguélez Cavero, who presents a comprehensive and exhaustive study of gestures in the Iberian world. Following Garnier, I will analyze the iconographic language as a construction based on a combination of figures, which evolves and is enriched according to the creation and stabilization of its morphology and syntax across time and space. In line with Miguélez, I will conceive gestures in a loose sense: as movements of one or several parts of the body that perform an action or show inward affections, accounting for an integral part of the communicative 
woodcuts conveyed the emotions of scenes on the page. It also explores the significant implications of the decisions taken by illustrators whenever they privileged certain gestures. Furthermore, I would also examine whether or not these gestures were being readily understood by contemporary readers, and whether they preserved or showed traces of theatrical performances. ${ }^{4}$

Rhetoricians, philosophers, educators, and playwrights have made gestures their object of interest through the ages. ${ }^{5}$ During Antiquity and the early Middle Ages, preachers, monks, and performers made ample use of them. In classical antiquity, rhetoricians were mainly concerned with gestures suitable for the orator, and barely treated actors' gestures or gesticulations, because they deemed them inappropriate for public speakers. ${ }^{6}$ Aristotle and Quintilian, regarded gestures as part of the oral delivery, actio or elocution, and as a complementary tool facilitating understanding in a diverse audience. ${ }^{7}$ The growing relevance of religious preaching and school debates marked a revival in the interest for gestures in the Middle Ages. An early medieval grammarian, Geoffrey of Vinsauf, conceived of them as a necessary complement to communication. His contemporary, the Italian scholar Boncompagno da Signa (1170 ca.-1240 ca.), tried to systematize them, recording, for instance, how women in Tuscany expressed grief by lacerating their faces. ${ }^{8}$ From the tenth century on, communities of Catholic monks who adhered to the vow of silence made use of gestures as a lexicon that enabled them to communicate. The importance of this monastical practice is attested by the fact that gestural communication became an object of satire during the Middle Ages —as in the episode, "Dispute between the Romans and the Greeks", included in the fourteenth-century Spanish Libro de Buen Amor, or the sixteenth-century

process. I also take into consideration the contexts in which those gestures were produced, and the interaction they might have had with their audiences.

4.- For this purpose, I have compiled an archive of early sixteenth-century illustrated editions of Celestina with original woodcuts other than factotums. I am extremely grateful to the curators of the Hispanic Society of America, John O'Neill and Vanessa Pintado, to the librarians of the Biblioteca National de Catalunya, and to Enrique Fernández Rivera and the public online database, Celestina Visual <http://www.celestinavisual.org/>, which contains a collection of the illustrated title pages of many Celestina editions.

5.- For a more detailed introduction to the history of gestures, see Schmitt, pp. 15-40, and Miguélez Cavero, pp. 13-23.

6.- Through the study of a Terentian manuscript (modeled on illustrations dating back to the third century), Dodwell has noted that some of the gestures described by Quintilian in his Instituto Oratoria had been used in classical Roman performances.

7.- Quintilian, Institutio oratoria (book 11, chapter 3) pp. 85-91. As noted by Quintilian in his chapter on delivery, pronuntiatio was often called actio. Thus Cicero divides actio «in two elements, voice and movement, and these are also the elements of pronunciatio» (Quintilian, p. 87).

8.- Knox, p. 12. 
French Pantagruel, with its Dispute of Panurge and Thaumaste. ${ }^{9}$ Besides, the development of a gestural language was often intrinsically related to that development of liturgical drama in that dramatic gestures and iconography helped shape each other. ${ }^{10}$

Conceived as an utopian transnational language that would make it possible to achieve a greater understanding among men, an even sharper interest in theorizing gestures emerged in the early modern period. ${ }^{11}$ This theorization transcended disciplinary boundaries, going beyond the scope of rhetoricians, monastic lexicons, and actors' postures. It was a view shared by geographically diverse and dispersed authors, such as Arias Montano, in his biblical commentaries (1571); Giovanni Bonifacio, in his L'arte de' Cenni (1616); or John Bulwer, in his Chirologia and Chironomia (1644). Bulwer, among the first scholars to undertake the study of gestures, explored the communicational challenges of deaf-impaired people, and the use they made of signs. In Spain, the educator, Juan Pablo Bonet, had already pursued the same aim twenty years earlier. Inspired by contemporary practices, in 1620 he printed an alphabet of hand signs for the deaf. Contemporaneously, painters, sculptors, and artists likewise renewed their interest in mastering the movements and gestures of the body in order to convey emotion in art. In 1688, the painter Charles Le Brun would offered a whole treatise, Méthode pour apprendre à dessiner les passions, as a repertory of gestures and facial expressions artists could use. ${ }^{12}$ This artistic focus on mastering the movements of the body was already central in discourses that had originated a century before Le Brun's treatise, and which were, therefore, written few decades after the earliest Celesti$n a$ 's woodcuts. This was the case of the work by Giovanni Paolo Lomazzo (1538-1600), Trattato dell'arte de la pittura, scultura, et architettura (1584), which discusses the representation of human emotions through art.

Scholars who edited and printed comedies by the late fifteenth century seem to have faced similar concerns. They were most attentive to the "legibility» of engravings and illustrations, which were expected to be understandable to everybody, even the illiterate. Editors of Terence showed a particular interest in declaring the importance of engravings as a way to make the plot of a comedy visible. Although containing no specific note about the gestures, the commentaries of the edition of Terence's Comedies (Treschel, Lyon, 1493) regarded engravings as being able

9.- It is worth mentioning that ancient and medieval rhetoric were less inclined to think about gestures as a transnational language that could be learnt and taught, as it would be the case in the early modern era (Knox, pp. 14-15).

10.- For further information on the relationship of medieval iconography and liturgical drama, see Miguélez Cavero, pp. 296-301, and Abajo Vega.

11.- For an analysis of some of the reasons behind the renewed interest in the systematic study of gestures as a transnational language, see Knox, pp. 16-24.

12.- For an analysis of the innovations of Le Brun's treatise, see Miguélez Cavero, p. 14 
to convey the unfolding of the plot to an illiterate person, who would no longer need to read the text in order to make sense of it. Critics have long considered the commentaries of Guido Juvenalis, complemented by Jodocus Badius, as being at the vanguard of the rediscovery of classical theater. ${ }^{13}$ Badius, in fact, advanced the idea of an iconographic program able to be understood without the written text. Such program relied on the use of illustrations, in which a correlation of characters, their dimensions, gestures and postures, objects, and choice of clothing, were indispensable in conveying the storyline. According to Badius, "even the illiterate could read by looking at the images that precede some scenes in the comedies, and thanks to them understand the comic plot». ${ }^{14}$ The emphasis on the importance of illustrations and their intrinsic value to readers is not unique to this edition. The 1496 edition of Terence's Comedies, published in Strasburg by Johann Grünninger, also highlights the importance of the factotums in making the plot understandable to all.

Critics consider the engravings in both these editions as possible sources for the woodcuts of Fadrique de Basilea's Comedia de Calisto y Melibea (Burgos, 1499). ${ }^{15}$ These early woodcuts would be highly influential in the design of Celestina's iconography in later editions. They also helped visually to place the work in the context of the genre of theatrical illustrations. ${ }^{16}$ The preliminary materials of the Comedia de Calisto

13.- According to Hemand-Schebat, the typographical innovations originating in the ninth- and tenth-century manuscript sources for Terence's Comedies that take place in Trechsel's printed edition imply that the engraver had in mind an actual theatrical representation, with the scenes belonging to a staging of the works: «Pour corriger l'aspect souvent statique et figé des personnages représentés dans les manuscrits, le graveur de l'édition de Trechsel opère une véritable théâtralisation. Il enrichit le décor auquel il donne les caractères contemporains d'une scène de théâtre. Il matérialise dans la gravure ci-dessus la scène sur tréteaux encadrée par des statues d'Apollon et Bacchus, dieux qui président au théâtre. Ses illustrations témoignent donc d'une mise en action de la représentation» (p. 12).

14.- «Si quidem quia sensa poetae tam aperte a Guidone nostro exposita sunt ut vel novellus in litterarum militia tyro sine veteratoris praesidio capere posset: effecimus ut etiam illitterati ex imaginibus quas cuilibet scaenae praeposuimus legere atque accipi comica argumenta valeat» (in Terentius, fol. Q4 verso).

15.- For further notice on the influence of the engravings of the 1493 and 1496 Terence editions on the 1499 Comedia de Calisto y Melibea, see Rodríguez-Solás, and Cull.

16.- As Rodriguez-Solás has observed: «La Celestina, al adoptar el modelo editorial de las ediciones de Estrasburgo y Lyon, se inscribía a sí misma en la tradición terenciana» (p. 16). In the same line, Griffin has noted, regarding Fadrique de Basilea's inspiration in Grüninger's edition: «Significantly, the book to which Fadrique de Basilea turned as a model for his illustrations was an edition of Terence. This suggests that its first known printer considered Celestina to be a descendant of classical comedy and to form part of a long tradition of drama» ( $\mathrm{p}$. 68). According to Garnier, it is essential to take into account the context of an image to carry out an accurate iconographic analysis. This implies the study of the literary genre as well: "On entend par contexte l'ensemble des éléments qui ne sont pas contenus dans l'image, mais appartiennent à son environnement: domaine (juridique, médical, religieux...), genre littéraire (théâtre, roman, exemplum, épopée, satire...) thème général (amour, mort, combat spiritu- 
y Melibea, published in Toledo (1500) and Seville (1501), confirm the connection between Celestina and the dramatic tradition of Terence's comedies: "Jamás yo ví terenciana, después que me acuerdo, ni nadie la vido, obra de estilo tan alto y subido, en lengua común vulgar castellana». ${ }^{17}$ Subsequent sixteenth-century editions concurrently placed the Tragicomedia in the dramatic tradition. As Clive Griffin has noted, Alonso de Ulloa explained in the prologue to his edition of Celestina (Venecia, 1553): «that he was adopting a layout which he considered appropriate for a work which (...) formed part of the tradition of 'las comedias de Terencio y de Plauto'». ${ }^{18}$ In this regard, Ottavio Di Camillo has asserted that the argumento of the Comedia de Calisto y Melibea follows a Terentian model. Furthermore, given its sources and function, it may have been composed by an actor for its recitation, or by the original author following the classical practice. ${ }^{19}$

Numerous scholars have recently pointed out the importance of woodcuts as sites in which to explore the contemporary readings of Celestina. ${ }^{20}$ Adding to this line of inquiry, I will aim in what follows to reconstruct the meanings there conveyed according to medieval and early modern gestural codes. Conceiving woodcuts as being inscribed in a particular historical time, and depending on both the visual genre of the theater and that of the sentimental novel, ${ }^{21}$ I will advance interpretative hypotheses regarding the iconography of the different representations of the title

el...). Le contexte est donné par les ensembles dont la représentation fait partie (manuscrit médical, tympan roman, cycle hagiographique dans un vitrail, etc.)» (vol. 1, p. 23).

17.- In his critical edition of the text of the Comedia de Calisto y Melibea, Canet y Vallés opens his study of the literary genre associated to this early stage of the work precisely with the words contained in those preliminary materials. He follows in this way a long-standing current of scholarship that has emphasized the important ties between the Comedia and humanistic comedies (p. 31).

18.- Griffin, p. 68.

19.- As Di Camillo notes, «es muy posible que este argumento fuese compuesto, como veremos más adelante, por algún actor para la recitación o declamación de la comedia, de acuerdo con los argumentos que se encuentran al comienzo de las comedias de Terencio en los impresos que circulaban durante las últimas décadas del siglo XV» («Pesquisas», pp. 81-82).

20.- Among them, the contribution of Fernández Valladares presents a study focused on analytical bibliography that surveys the illustration of a local corpus of chapbooks (pliegos sueltos) produced in Burgos (p. 87).

21.- Art historians have long been concerned with the question whether gestures portrayed in woodcuts associated with a dramatic tradition (such as those in the editions of Terence's Comedies) could present traces of a performance, that is, the possibility that they could somehow reflect classical or contemporary performance techniques, instead of being a mere copy of textual models. This question has been answered somehow differently through the last century. The works by Dodwell on the Anglo-Saxon Gesture and the Roman Stage, and Barasch on Gestures of Despair or Davidson in Medieval British drama, seem to point out that, as much as gestures traveled from one tradition to another and are, or were therefore copied and imitated, some of them could be decoded by readers at certain points of history, enabling the possibility of the gestures being a reflection of contemporary stage practices. 
page situated before the argumento del primer acto. My approach considers gestures as part of a web of signifiers in meaningful interaction, deeply linked to coeval and generic conventions. For this purpose, I have relied on the valuable contribution of scholars, such as François Garnier, Jean Claude Schmitt, Charles Reginald Dodwell, Moshe Barasch and Alicia Miguélez Cavero, and their studies of medieval and early modern gestures. As noted by François Garnier, images reproduced in the first printed books (due to their dimensions and their technique) often simplify the contents of the representations, highlighting the essential conventional language from previous centuries. This, in turn, lends legitimacy to the use of these conventions for the analysis of early fifteenth- and sixteenth-century engravings and woodcuts. ${ }^{22}$ In the following pages I will survey the different choices made by printers and engravers of both the Comedia de Calisto y Melibea and the Tragicomedia de Calisto y Melibea. Focusing on their iconographic programs, I will divide the text in four epigraphs that account for the four main trends in Celestina's title-page illustration during the sixteenth century: Melibea's garden or country house, Melibea's palace or chapel, Celestina as a rising character placed in Melibea's bedroom, and a fully dramatic setup of the plot following the conventions of the late fifteenth-century engravings of Terence's comedies.

\section{Lovers' encounter in Melibea's garden or country house}

The 1499 Comedia of Burgos, printed by Fadrique de Basilea, established one of the dominant models for the interpretation of the first encounter between Calisto and Melibea. At the avant-garde of printing innovations, Fadrique de Basilea's illustrations were modeled after contemporary figures and reproduced details that appeared in theatrical editions of Terence's Comedies recently printed in Ulm (1486), Lyon (1496), and Strasbourg (1496). However, as Vanessa Pintado has proved, Fadrique de Basilea's illustrations cannot be considered simple copies, since they have been significantly modified in relation to their models, ${ }^{23}$ becoming more dynamic than their predecessors. ${ }^{24}$ Worth noting is that Fadrique de

22.- «Elle traduisent les idées, les sentiments, les comportements en empruntant au langage conventionnel médiéval» (Garnier, vol. 1, p. 26).

23.- As noted by Pintado, the woodcuts printed with the text were crafted specially for this edition (pp. 337-38).

24.- Pintado: "Contrario a los personajes estáticos de las ediciones de Terencio, los de la Comedia de Burgos tratan de representar no sólo el tono anímico de la situación en que actúan sino también la dinámica de la acción, lo que no se da a menudo en los incunables de Terencio» (p. 341). Rodríguez-Solás: «Si examinamos los grabados de Burgos es inevitable ver el modelo de Estrasburgo en el árbol del primer grabado, en la casa que aparece en el primero y en otros grabados o en la representación de Pleberio. Pero hay una diferencia entre estas dos ediciones que salta a simple vista: el Terencio de Estrasburgo representa escenas bidimensio- 
Basilea's woodcuts were to influence many editions to come, and would also contradict the text itself. As Joseph T. Snow has shown, they became a model for the Cromberger's Sevillian editions, and inspired the ones produced in Venice in 1531 and 1534 by Juan Bautista Pedrazano and Stefano da Sabio respectively. ${ }^{25}$ The initial woodcut (see FIGURE 1), placed before the Argumento del primer auto de esta comedia, as Berndt Kelley notes, illustrates «the encounter and dialogue between Calisto and Melibea as recounted in the argumento». ${ }^{26}$ The dialogue takes place in what seems to be a garden, or rather, according to Ottavio Di Camillo, a natural landscape in a country house. We might interpret the image as portraying Melibea expressing certain receptivity towards $\mathrm{Calisto}^{27}$ as she greets him with her palm open to the exterior ${ }^{28}$ while Calisto holds his cane with his fist closed. The secant position of Calisto's feet is a sign of action. ${ }^{29}$ It could mean that Calisto has been walking in the fields while hunting with his falcon (on the tree on the right side), or perhaps that he will be soon departing hastily. ${ }^{30}$ According to this reading, the woodcut illustrates the first phrase corresponding to the summary of the first act: ${ }^{31}$ "Entering Calisto in a garden pursuing a falcon, he saw Melibea and immediately started to talk to her. After having been dismissed by her firmly, he returns home anxious (emphasis added)». ${ }^{32}$ This reading would require confirmation through an extensive analysis of similar characters in analogous contexts and literary genres. A different interpretation is also possible by taking into account the second part of the summary. In this case, Melibea's gesture can be understood as a rejection following her short conversation with Calisto, thus corresponding to a sign that in John Bulwer's Chirologia indicates punishment (castigo). If such a hypothesis were confirmed, then the illustration would portray the moment of Melibea's rejection instead of that of Calisto's proposition, echoing the severe farewell of Melibea: «Enter-

nales y estáticas, mientras que La Celestina de Burgos, pudiendo optar por la solución más sencilla, que consistiría en representar en el grabado a los personajes que intervienen en cada acto, elige la ilustración detallada de una o varias escenas del acto que se caracterizan por el movimiento de los personajes» (p. 3).

25.- Snow, «La iconografía», pp. 255-57.

26.- Berndt Kelley, p. 19.

27.- The model of Calisto's figure is that of Trasso, while Melibea would be based on the figure of Pitias from Terence's comedies, as published by Grüninger in Strasbourg in 1496 (Berndt Kelley, pp. 338-39).

28.- For an analysis of the symbolism of having the palm open, see Garnier, vol. 1, pp. $173-75$.

29.- Garnier, vol. 1, p. 232.

30.- Garnier, vol. 1, p. 96.

31.- An attentive analysis of the interplay between the mise en page of the text and image of this woodcut and its plausible implications can be read in Rivera, pp. 7-8.

32.- Signature $\mathrm{a}_{\mathrm{i}}$, Comedia de Calisto y Melibea, Burgos, 1499. The translation is mine. 
ing Calisto in a garden pursuing a falcon, he saw Melibea and immediately started to talk to her. After having been dismissed by her firmly, he returns home anxious (emphasis added)».

Another detail of the woodcut that would influence subsequent iconographic readings of this very same episode is the partial view of Melibea's house on the left, which prefigures a tower and forebodes Melibea's eventual death. Four trees stand in Melibea's garden, or what seems to be a landscape in the countryside, with a falcon perched on one of them on the left side of the illustration..$^{33}$ The presence of the falcon in the summary of the first act is strange since it is mentioned, and only in passing, in the second act, which, as Di Camillo has noted, was most likely introduced by Fadrique de Basilea or the person commissioned to write the arguments according to the actions presented in the preexisting initial woodcut. The initial woodcut, however, should correspond to the Comedia's general Argumento, which must have been printed on the verso of the now lost first folio. In fact, each of Fadrique de Basilea's woodcuts follows its corresponding argument, and the appropriate woodcut for the first act is printed on the verso of the second folio (original signature aiiv). ${ }^{34}$

This first interpretation of the work's title page, as a conversation between the lovers (either at the point of the proposal or the refusal), has conditioned generations of critics and readers. ${ }^{35}$ Adaptations of the iconographic program of the 1499 Comedia de Calisto y Melibea model appeared in several editions throughout the sixteenth century: from the cover of the Comedia de Calisto y Melibea (Toledo, 1500) to the Comedia de Calisto y Melibea (Sevilla, 1501), to the woodcuts of nearly all the early Tragicomedia de Calisto y Melibea. The Toledo edition of the Comedia incorporated interesting variations regarding the gestures chosen by engravers to portray the lovers' encounter (see FIGURE 2). A new figure, Celestina, appears on the right side of the title page. While turning her back to the couple, she carries a skein on her right hand, ${ }^{36}$ leaning her left hand against the wall of Melibea's house. Melibea points her index finger to the floor, while Calisto, with his fist half-closed, seems to be pointing with his thumb up, while holding a falcon on his left hand. The woodcut suggests Melibea's refusal of Calisto's pretentious words. This gesture was used during the Middle Ages as a way of communicating personal will and superiority. In this case, the gesture could be interpreted as the artist's interest in portraying Melibea's higher social rank, or her moral

33.- For an analysis of the symbolism of the hawk as a mark of carnal lust and the sport of hunting in the context of medieval iconography, see Barbera.

34.- Di Camillo, Pesquisas indiciarias, p. 89.

35.- The first scene of the work, according to internal textual evidence, is likely to have taken place in a church (Di Camillo, "When and Where», p. 108).

36.- For an analysis of the symbology of Celestina's thread as a metaphorical association with her occupation of mending maidenheads, see Montero, p. 41. 
uprightness. ${ }^{37}$ In turn, Calisto's bodily interaction was commonly associated with excessive pride and personal will..$^{38}$

Closely following Toledo's woodcut, the Seville edition of the Comedia (1501) depicts two new key figures: Melibea's servant Lucrecia, standing to the left of her mistress, and a horseman, on Calisto's far right (see FIGURE 3). The body language of some characters already appearing in Toledo's title page have been modified. On the far left, Celestina knocks at Melibea's door instead of pushing it, while the gestures of Calisto and Melibea reproduce almost identically those of Toledo. Calisto's fist is slightly closer, with a thumb leaning backwards, a gesture that in Bulwer Chirologia has been catalogued as "demonstrat». ${ }^{39}$ The image therefore, even though conveying a reading similar to that of Toledo, adds the notion of a less covetous Celestina, who respectfully knocks instead of pushing the door. It also offers a different setting for the couple. Lucrecia, witness of the sexual encounters of the lovers, is present also here, as is the horse, whose meaning has largely been discussed by the critics as a symbol of lust. The horseman most likely corresponds to one of Calisto's servants, either Pármeno or Sempronio. However, the lack of an inscription above the figure raises the question whether the horseman could also represent Calisto in the act of entering into the garden, given the similarity of both figures' clothes. The wood block, as Clive Griffin has showed, was reused shortly afterwards, when Jacobo Cromberger took control of this press in Seville: "He reused the same block for several editions of the Tragicomedia. The first surviving one of these was printed in about 1511, some ten years after Polono's Comedia». ${ }^{40}$ The block appeared again in Cromberger's 1518 Libro de Calixto y Melibea y de la puta vieja Celestina (see FIGURE 4). Other printers would use a very close reproduction of this woodcut, as in the case of the 1520 edition by Antonio de Salamanca. This scene is almost identical to that of Seville, except for the hairstyles of Lucrecia and Melibea (see FIGURE 5). ${ }^{41}$

From among this series of near-identical title pages, the wood block in the edition printed in Burgos by Juan de Junta (1531) introduces an in-

\section{7.- Garnier, vol. 1, p. 165.}

38.- According to Garnier, hands at the height of the thigh denote the excessive and sole nature of a passion or a vice (vol 1, p. 134).

39.- The gesture above mentioned (demonstrat) appears in the passage devoted to "An Index to the Following Alphabet of Action, or Table of the Rhetorical Indigitations".

40.- However, the woodcut had been probably used earlier in editions now lost, since the title page block was by 1511 already in a poor condition. See Griffin, p. 61.

41.- The chronology and place of publication of the edition, here noted as Antonio Blado for Antonio of Salamanca [?]: Rome [?], 1520, now held at the Hispanic Society of America, New York, has been disputed by several scholars. 
teresting variation (see FIGURE 6). ${ }^{42}$ Being an inverted copy, it portrays from right to left Celestina knocking at the door, skein in hand, together with a group of four figures, composed by Lucrecia, Melibea, Calisto, and a character who looks like one of Calisto's servants, most likely Sempronio. ${ }^{43}$ The position of the figures and their interrelation emphasizes here a different aspect that provides yet a further description of Celestina's plot. Both Sempronio and Calisto appear to be interacting and touching with their left hands other characters within the group of figures. ${ }^{44}$ In fact, Sempronio appears to be pushing Calisto, encouraging him to take action towards Melibea, as if he were enabling the action to happen via Celestina. ${ }^{45}$ Calisto exerts a similar pressure on Melibea, posing his hand on her back, as if forcing her to accept his proposition. The pressure exerted on Calisto and Melibea is further confirmed by the position of their feet: Both Sempronio and Calisto have their left foot placed forward in a secant position. As discussed before, this position is often meant to indicate the imposition of personality and will. As a consequence, such positioning could be hypothetically read as the illustrator wanting to expressly mark the influence of Sempronio over Calisto, as well as that of Calisto over the will of Melibea. Melibea's response to Calisto's advances continues to be negative, since she appears to reject Calisto's proposition, with her arms significantly closed above her belly in a gesture of stubborn refusal. ${ }^{46}$

A last variation of the same scene in the title page used by Juan Batista Pedrazano in 1523 (see FIGURE 7), which was reused in Italy for later editions of the Tragicomedia by Pietro de Nicolini da Sabio (1541), and Bernardino de Bendoni (1543) included new elements on scene, such as a dog, and a rosary on Celestina's hands. The woodcut depicts a group of five figures from left to right: Celestina, Lucrecia, Melibea, Calisto and a horseman explicitly identified here as Sempronio. It also adds a dog to the scene, an animal common in portraits of the nobility for its symbolic value. Calisto and Melibea are having a conversation in which Me-

42.- It is worth noting that Juan de Junta took care of Fadrique de Basilea's press, as he came to be the second husband of Fadrique's widow, Isabel de Basilea. See Fernández Valladares, p. 91.

43.- Whereas no name has been inscribed above the illustration, I am inclined to think that the figure on the left represents Sempronio rather than Calisto, since both characters wear different clothes in what seems to be an effort by the engraver to distinguish them.

44.- For a reading of a similar gestural interaction among characters, see Garnier, vol. 1, pp. 64-66.

45.-According to Garnier "lorsqu'un personnage situé derrière un autre lui pose la main sur le dos — principalement sur l'épaule - ce geste exprime la pression exercée pour faire accepter une proposition ou accomplir une action. Qu'il y ait ou non poussée physique, ce que l'image ne permet pas toujours de discerner, ce geste peut se traduire par: encourager quelqu'un à, pousser quelqu'un à, contraindre quelqu'un à» (vol. 1, p. 190).

46.- Garnier, vol. 1, p. 185. 
libea's gestures have been modified as she faces Calisto with her hand upwards and her index finger up, probably indicating her opposition to Calisto's proposition. ${ }^{47}$ Other elements have been redesigned: Melibea's house displays two windows, and Celestina does not carry a skein but a rosary, thus highlighting her feigned devotion instead of emphasizing the episode in which she carries the witched skein to Melibea's house.

\section{Melibea's palace or private chapel}

The Tragicomedia de Calisto y Melibea (Zaragoza, 1507), printed by Jorge Coci, contains a completely different rendering of the scene (see FIGURE 8). It inscribes the couple in the genre of the sentimental novel and within the conventions of courtly love or fin' amors. However, this illustration was not commissioned for the occasion but rather belongs to an earlier edition of La cárcel de Amor (1493). ${ }^{48}$ The title page is significant for being the only one not associated with the printing conventions of the dramatic genre. This exception, as shown by Clive Griffin, further proves the extent to which the majority of Celestina's early editors and printers viewed the work as being deeply linked to a dramatic tradition. Jorge Coci probably chose the woodcut because it could be interpreted as a depiction of Melibea sitting on a throne with Calisto kneeling in front and talking to her with his left hand open upwards, and his right hand holding his hat. This particular image adds to the long-standing debate over whether the first encounter between Calisto and Melibea took place in a garden, or a church (or, as we may appreciate in the woodcut, in a palace or a private chapel) ${ }^{49}$ It also seems to portray Melibea as belonging to a higher social status than Calisto, thus reflecting her "alta y serenísima sangre». ${ }^{50}$

47.- A similar gesture is recorded in the context of a discussion by Garnier, vol. 1, pp. 64-66.

48.- Griffin: «The earliest surviving Spanish-language edition of the Tragicomedia appeared in Zaragoza in 1507. (...) A complete copy has, however, recently come to light and turns out to contain a single woodcut which decorates the title page and depicts a courtly lover on bended knee before his lady (...). This woodcut was impressed from a block which had been commissioned for the first illustrated edition (1493) of Diego de San Pedro's Carcel de amor (....)» (p. 72).

49.- In this edition, Calisto appears as courtly lover, depicted as Melibea's servant. The lovers' encounter happens here in a rich decorated interior, more attuned with the actual location of the textual encounter in the first act. As Di Camillo notes when reviewing the corrupted readings of the first act, "there are, I am sure, reasons as to why this particular Act is plagued with so many serious errors, such as the location (...) (obviously a church rather than a garden) of the first dialogue between Calisto and Melibea» (Di Camillo, "When and Where», p. 108).

50.- Rojas, p. 82. 


\section{The rising of a character: La Celestina}

Another unique interpretation of the general plot of the story, which reveals a shift in the audience's tastes (as well as a proof of the ability of the printer to market a product adapted to new readers) was the Italian translation of the extended Tragicomedia de Calisto y Melibea, published in Venice in 1519 by Cesare Arrivabene (see FIGURE 9). The edition was advertised as «being adorned with many and most beautiful illustrations (...) which are not to be encountered in other editions of the work». Its title woodcut was a great success in Italy in the early sixteenth century: it was reused in many Italian editions, such as those of 1531 and 1535, and accounted for the increasing importance that the character of Celestina started to have in Italy at the time. Both the sixteen-act Comedia and the twenty-one-act Tragicomedia de Calisto y Melibea were popular in humanistic circles at the papal curia since the beginning of the sixteenth century. Apart from its plausible performance before Alexander VI in 1502, the go-between, Celestina, was mentioned in the 1504 Tratado de la corte romana compuesto en lenguaje castellano by Baltasar del Río. The Tragicomedia would be translated into Italian, and most likely also into Hebrew, a few years later in the entourage of Pope Julius II. Arrivabene's woodcut is unique in that it paid a great deal of attention to the encounter between the matchmaker and the maiden, leaving Calisto's intervention out of the frame. The go-between holds here a central position as the character enabling the plot. This change of emphasis goes hand-in-hand with the play's new primary title, Celestina, which thus relegates the original one, Tragicomedia de Calisto y Melibea, to the function of a secondary subtitle. In fact, as Ottavio Di Camillo has noted, this is the first edition of the Tragicomedia that bears as its primary title the name of Celestina, a focus only preceded by the 1518 Sevillian edition, Libro de Calisto y Melibea y de la puta vieja Celestina..$^{51}$

Arrivabene's woodcut is located below the new title and the argument of the play. It represents Melibea and Celestina in Melibea's bedroom, having a conversation symbolically in front of Melibea's bed. Celestina leans towards Melibea while extending her hands to the young lady, in a gesture recorded by Bulwer as "neotericis orditur», 52 and commonly used to represent the benevolence of the interlocutor, a proposition, or the acceptation of another's point of view. ${ }^{53}$ The epigraph on the page reads: Vetula cauda scorpionis (old woman, scorpion's tail), revealing the character's danger-

51.- Di Camillo suggests that this change of title and of iconographic program encompasses a new way of reading the text (Di Camillo, "Algunas consideraciones», pp. 216-26).

52.- According to Bulwer, "the indulgent putting forth the hand towards the auditors, signifying a kinde of humanity and good will, is a benevolent action fit for those who praise or congratulate, and is of great efficacie to move the affections» (p. 30).

53.- Garnier, vol. 1, pp. 174-80. 
ous duplicity. As noted by Charles Reginald Dodwell, a similar gesture appears connoting supplication and associated with the servants of Terence's comedies, "like Pármeno in Eunuchus (...) or Geta in Adelphoe» in manuscripts dating back to the ninth century. ${ }^{54}$

\section{A Terentian set up: Valencia (1514), Barcelona $(1525,1531)$ and Zaragoza (1545)}

A complete refashioning of the scene is portrayed in the cover of the edition by Juan Joffre (Valencia, 1514). It follows a fully theatrical setup, recalling the $1486 \mathrm{Ulm}$ edition of Terence. It figures a street corner, with a couple in what seems to be the garden of the house on the far left. The woodcut portrays different scenes from the Tragicomedia in a single frame, as in the engravings illustrating the storyline of Terence's Comedies in Johann Grüninger book (Strasbourg, 1496) (see FIGURE 10). As noted by Mark P. O. Morford, one of the most remarkable of Grüninger's innovations consisted of engravings featuring a full-page bird's eye view. This view portrayed «each play's characters (each named) and their situations, made especially clear for pairs of characters who were connected by straight lines». ${ }^{55}$ In the Valencia woodcut, four groups of figures are simultaneously emphasized: two women and two men, vivaciously engaged in a discussion on a street corner, located at the top right of the image (see FIGURE 11). They represent most likely Pármeno, Sempronio, Elicia and Celestina. ${ }^{56}$ Beneath these figures, on the left, Celestina knocks at Melibea's house with her left hand. She is covered with a long cloth (or haldas), which she holds with her right hand at the height of the hip. No skein or rosary is depicted on the image, and yet the tension of Celestina's crossed arms and her straight posture convey an unusually strong characterization that goes beyond feigned piety or carrying the witched skein. Her representation can be read as that of an old lady characterized by the determination suitable to her task as a go-between. ${ }^{57}$ It also highlights the importance of Celestina's haldas, which she has to lift in her way to Melibea's house in act four while trying to read all the positive omens she encounters on her way:

\section{4.- Dodwell, p. 17.}

55.- Morford: "On the page opposite [to this full-page bird's eve views], the editor (Jodocus Badius Ascensius, who had also been Trechsel's editor) supplied an explanation, figurae declaratio, with the descriptive subtitle (for Andria) 'a clearer explanation of the plot according to this illustration'» (p. 133).

56.- I am inclined to think that this figure represents Celestina (and not Areúsa), given the clothing of the character, which reproduces that of the procuress below.

57.- Garnier, vol. 1, p. 185. 
Las piedras parece que se apartan y me hazen lugar que passe; ni me estorvan las haldas, ni siento cansancio en andar; todos me saludan. Ni perro me ha ladrado, ni ave negra he visto, tordo ni cuervo ni otras nocturnas. Y lo mejor de todo es que veo a Lucrecia a la puerta de Melibea. Prima es de Elicia: no me será contraria (emphasis added). ${ }^{58}$

The woodcut further depicts Melibea at the right window in the second floor and in the next window to the left, Pleberio and Alisa closely observe Celestina's movements. To the right, three figures in motion, Calisto, Pármeno, and Sempronio, are approaching Melibea's walled garden. Facing them, Lucrecia and Melibea are having an animated conversation within its boundaries. The artist chose to illustrate the moment in which the two women are waiting for Calisto's arrival. At a glance, the image illustrates all the key scenes of the plot: the hiring of the procuress, her visit to Melibea's house, the ultimate impact on Melibea's parents, as well as the nightly visit of Calisto to Melibea's garden with the assistance of his servants and Lucrecia as a witness. In short, the woodcut synthesizes the most significant scenes in the plot of the Tragicomedia.

The same wood block was later used for the editions of the Tragicomedia de Calisto y Melibea printed in Barcelona by Carles Amoros in 1525 and 1531 (see FIGURE 12), and also served as a model for the title page of the 1545 edition printed in Zaragoza by Jorge Coci for Pedro Bernuz and Bartolomé de Nájera. Similarly to the woodcuts of the title page of the Comedia of Toledo (1500) and Seville (1501), which were reused for the next twenty years in editions of the Tragicomedia, printed in Toledo and Seville, the one from Valencia (1514) was used again and again by printers of Celestina in Valencia and Barcelona for many years. This parallels the reutilization of woodcuts in the Italian editions of Arrivabene (1519) and Pedrazano (1523). This practice highlights the extent to which, while books and ideas for similar iconographical programs might travel far, wood blocks tend to have a narrower circulation, confined to the printing press in which they were printed, and to their heirs or buyers.

Built upon the model of an equally theatrical set up, the title page of the edition printed in Zaragoza in 1545 by Coci (see FIGURE 13), emphasizes the importance of Melibea's house, where the main actions take place, by bringing it to the foreground, almost as a close-up. All characters stand out by their dynamism: Celestina is knocking at the door under the attentive glance of Melibea, who is leaning at the window in the upper floor; on the street, Calisto runs to Melibea barely able to rein back his horse, and rushes to mount up to the garden on the first floor, to declare his love to her. Many of these symbolic elements have appeared in previous editions: Celestina's skein from the Toledo edition of the Co- 
media; Calisto's horse from Polono's edition; the depiction of Calisto and Melibea in a walled garden from the Valencia edition of the Tragicomedia. A reinterpretation of this woodcut would be printed by Francisco Fernández de Córdoba in Valladolid, 1561 (see FIGURE 14). The wood block in it is much smaller, and we can only see Melibea at the window in the center, a partial figure of Celestina on the left, and those of Calisto and his horse directly below Melibea. On the right, but slightly lower than Melibea, one may see Calisto with his falcon, which in fact looks more like a pigeon. Even if the style has been notably redesigned, the Valladolid edition keeps the same figures, allowing for similar postural readings as the one published in Zaragoza: Celestina knocking at Melibea's door, Melibea leaning out of the window, Calisto arriving with his strong horse, and Calisto and Melibea conversing in the garden. A simplified version of the more detailed wood block that was used in the Zaragoza edition of 1545, now without the horseman, had appeared almost ten years earlier in Toledo by Juan de Ayala (1538) (see FIGURE 15). Although portraying only two scenes of the work, Celestina and Melibea's interaction, as well as the encounter of the lovers in the garden, Juan de Ayala's version emphasizes the characterization of some of the figures. On the right side, in addition to carrying a skein, Celestina is wearing the necklace that Calisto had given her in payment for her services, and a cane, symbolizing her old age. Melibea's face is depicted as if looking at the procuress with attention. On the left side, the encounter of the two lovers takes place in Melibea's walled garden. As the lovers converse, they mirror each other's gestures. Melibea holds a fan in her right hand, while her left index finger points to Calisto; in front of her, Calisto imitates the gesture with his right hand, but has a falcon on his left. The type of relation established by both figures seems to denote a discussion between them that could represent an opposition of ideas. ${ }^{59}$ The fan in Melibea's hand and the falcon in Calisto's define their social status as an aristocratic lady and a young nobleman.

\section{Conclusions}

As we have seen, the analysis of body language in Celestina's title pages further confirms the inscription of the work by most contemporary printers and readers within a dramatic iconographic tradition. ${ }^{60}$ This tradition was, by the turn of the sixteenth century, openly concerned with

59.- As Garnier has noted, the imitation of an equal figure often marks an opposition that could entail a conflict or a discussion (vol. 1, p. 54).

60.- This confirms the importance conceded by Carmona Ruiz to the study of woodcuts as a graphic reception of a literary genre: "Curiosamente, la xilografía puede utilizarse para apuntalar posturas sobre el género e intención de La Celestina, puesto que en el fondo brota 
the legibility of illustrations that would help the readers understand the text. However, engravers enjoyed certain flexibility as they summarized the plot of the (Tragi)comedia and codified the emotions on the page. A review of the iconographic trends of the title-page woodcuts reveals how printers operated under at least three distinctive iconographic programs: the encounter of the lovers in Melibea's garden, the depiction of Celestina in Melibea's bedroom, and a condensation of Celestina's plot on a theatrical stage populated by groups of figures and successive actions. In all these three main displays, the changes within the figures' body language, or any modifications to the iconographic program, could convey different readings of the characters' intentions and inner feelings. They were portrayed refusing or accepting a proposition, revealing a covetous personality, or concealed motives - as with the hidden hands of Calisto and Sempronio in the 1531 Burgos' edition. The different choices made by printers provide insight into contemporary readings, and enables us to ponder which elements of the plot were highlighted over others, and what their specific connotations were. As a way of illustration, Celestina's agency could be depicted through several objects that, when emphasized in the image, balance the importance of specific aspects of the plot: the rosary highlights Celestina's feigned piety; the skein might reinforce Celestina's witchcraft or act as merchandise accounting for the importance of urban economy; the gold chain denotes Celestina's thirst for money and the importance economical transactions play in the Tragicomedia, as aptly noted by Maravall. ${ }^{61}$ This line of inquiry is a preliminary approach to the study of the body language in Celestina's illustrations that should be complemented with an extensive analysis of similar figures in analogous contexts and literary genres. Also, the study of different episodes within the work, such as Celestina's killing and Melibea's suicide, in which I am currently working, may reveal new data that will complement the present investigation.

como 'recepción gráfica' de sus lectores» (p. 81). The exception is the Zaragoza edition of 1507, whose woodcuts were not commissioned for the occasion.

61.- Maravall, p. 63. 


\section{Bibliography}

ABAD, Martín, "La ilustración de portadas de La Celestina, en siete ediciones del siglo XVI», Revista de las ideas estéticas, 35 (1977), pp. 229-35.

Abajo Vega, Noemí, "Arte románico y teatro litúrgico: las posibilidades de un método en el estudio de la iconografía», Codex Aquilarensis, 21 (2005), pp. 111-31.

Alvar, Carlos, "De la Celestina a Amadís: el itinerario de un grabado», Filologia dei testi a stampa (area iberica), ed. Patrizia Botta, Modena, Mucchi Editore, 2005, pp. 97-109.

Barasch, Moshe, Gestures of Despair in Medieval and Early Renaissance Art, New York, New York University Press, 1976.

Barbera, Raymond E., "Medieval Iconography in the Celestina», Romanic Review, 61 (1970), pp. 5-13.

Berndt Kelley, Erna, "Mute Commentaries on a Text: The Illustrations of the Comedia de Calisto y Melibea», in Fernando de Rojas and Celestina: Approaching the Fifth Centenary, eds. Ivy Corfis and Joseph T. Snow, Madison, Hispanic Seminar, 1993, pp. 193-227.

Bonifacio, Giovanni, L'Arte de' Cenni con la quale Formandosi Favella Visibile, si tratta della Muta Eloquenza, che non è altro che un facondo silentio, Vicenza, Francesco Grossi, 1616.

Bulwer, John, Chirologia, or, The naturall language of the hand composed of the speaking motions, and discoursing gestures thereof: whereunto is added, Chironomia, or, The art of manual rhetoricke, consisting of the naturall expressions, digested by art in the hand ... : with types, or chyrograms, a long-wish'd for illustration of this argument, London, Tho. Harper, 1644.

Canet y Vallés, ed., José Luis, Comedia de Calisto y Melibea, Valencia, Universitat de València, 2011.

Carmona Ruiz, Fernando, "La cuestion iconográfica de la Celestina y el legado de Hans Weiditz», eHumanista, 19 (2011), pp. 79-112.

Celestina Visual, on line repository of the visual culture of Celestina, ed. Enrique Fernández, <http://www.celestinavisual.org/>.

Cull, John T., "A Possible Influence on the Burgos 1499 Celestina Illustrations: The German 1486 Translation of Terence's Eunuchus", La Corónica: A Journal of Medieval Hispanic Languages, Literatures, and Cultures, 38.2 (Spring 2010), pp. 137-60.

Del Río, Baltasar, Tratado de la corte romana en lenguaje castellano, Juan Besicke, Roma, 1504. 
Di Camillo, Ottavio, "Pesquisas indiciarias sobre el incunable acéfalo de la Comedia de Burgos", in Filologia dei testi a stampa (Area Iberica), ed. Patrizia Botta, Modena, Mucchi, 2005, pp. 75-89.

-, "When and Where was the First Act of La Celestina Composed? A Reconsideration", in "De ninguna cosa es alegre posesión sin compañia». Estudios celestinescos y medievales en honor del profesor Joseph Thomas Snow, ed. Devid Paolini, vol. 1, New York, Hispanic Seminary of Medieval Studies, 2010, pp. 91-157.

-, "Algunas consideraciones sobre la Celestina italiana», in Rumbos del hispanismo del Cincuentenario de la AIH, 8 vols., ed. Patrizia Botta, Roma, Bagatto Libri, 2012, vol. II, Medieval, ed. Aviva Garribba, pp. 216-226. Dodwell, Charles Reginald, Anglo-Saxon Gestures and the Roman Stage, Cambridge/New York, Cambridge University Press, 2000.

Fernández Rivera, Enrique, "La caída de Calisto en las primeras ediciones ilustradas de La Celestina», eHumanista, 19 (2011), pp. 137-56.

Fernández Valladares, Mercedes, «Biblioiconografía y literatura popular impresa: la ilustración de los pliegos sueltos burgaleses (o de babuínes y estampas celestinescas)», eHumanista, 21 (2012), pp. 87-131.

Garnier, François, Le langage de l'image au Moyen Âge. Signification et symbolique, vol. 1, Paris, Le Léopard D'or, 1982.

- Le langage de l'image au Moyen Âge. Grammaire des gestes, vol. 2, Paris, Le Léopard D’or, 1989.

Griffin, Clive, "Celestina's Illustrations», Bulletin of Hispanic Studies, 58 (2001), pp. 59-79.

Hemand-Schebat, Laure, "Texte e image dans les editions latines commentees de Terence (Lyon, Trechsel, 1493, et Strasbourg, Grüninger, 1496)», Camenae, 9 (june 2011), <http://www.paris-sorbonne.fr/IMG/ pdf/ARTICLE_9_Hermand-Schebat.pdf> [access November 20 2015]

Knox, Dilwyn, "Late Medieval and Renaissance Ideas on Gesture», in

Die Sprache der Zeichen und Bilder: Rhetorik und nonverbale Kommunikation in der frühen Neuzeit, ed. Volker Kapp, Marburg, Hitzeroth, 1990, pp. 11-39.

Le Brun, Charles, Conférence de Monsieur le Brun, premier peintre du Roi de France, chancelier \& directeur de l'Académie de Peinture et Sculpture, sur l'expression générale et particulière des passions, enrichie de figures gravées par B. Picart, Verone, A. Carattoni, 1751.

Lomazzo, Giovanni Paolo, Trattato dell'arte de la pittura, Milan, Paolo Gottardo Pontio, 1584.

Maravall, José Antonio, El mundo social de La Celestina, Madrid, Gredos, 1968.

Miguélez Cavero, Alicia, Gesto y gestualidad en el arte románico de los reinos hispanos: lectura y valoración iconográfica, Madrid, 45s Multimedia, 2010. 
Montero, Ana Isabel, «A Penetrable Text? Illustrations and Transgression in the 1499 (?) Edition of Celestina», Word \& Image, 21.3 (2005), pp. 41-55.

MoRFORD, Mark P. O., "Johann Grüninger of Strasbourg», in Syntagmatia. Essays on Neo-Latin Literature in Honour of Monique Mund-Dopchie and Gilbert Tournoy, eds. Dirk Sacré and Jan Papy, Leuven, Leuven University Press, 2009, pp. 119-36.

PINTADO, Vanessa, «El impresor Fadrique de Basilea y los grabados de la Celestina de Burgos de 1499", in De la piedra al pixel. Un recorrido por las edades del libro, ed. Laurette Godinas, México, UNAM, 2016, pp. 335-56.

Quintilian, M. F., Institutio oratoria, ed. Donald A. Russell, Cambridge, MA, Harvard University Press, 2014.

RIVERA, Isidro J., "Visual Structures and Verbal Representation in the Comedia de Calisto y Melibea (Burgos, 1499?)", Celestinesca, 19.1-2 (1995), pp. 3-30.

Rodríguez-Solás, David, "A la vanguardia del libro ilustrado: El Terencio de Lyón (1493) y La Celestina de Burgos (1499)", Bulletin of Spanish Studies, 86 (2009), pp. 1-17.

Rojas, Fernando de, La Celestina, ed. Dorothy S. Severin, Madrid, Cátedra, 2000.

Schmit, Jean Claude, La raison des gestes dans l'Occident Médiévale, Paris, Gallimard, 1990.

Snow, Joseph T., "La iconografía de tres Celestinas tempranas (Burgos, 1499; Sevilla, 1519: Valencia, 1514): unas observaciones», DICENDA. Cuadernos de Filología Hispánica, 6 (1987), pp. 255-77.

—, «Imágenes de la lectura/lectura de las imágenes: El caso de la Comedia burgalesa impresa por Fadrique de Basilea", Filologia dei testi a stampa (area iberica), ed. Patrizia Botta, Modena, Mucchi Editore, 2005, pp. 111-29.

Terentius Afer, Publius, Comedia sex cum comment[o] Guidonis Juvenalis, Lyon, Johan Treschsel, 1493. 
Figures

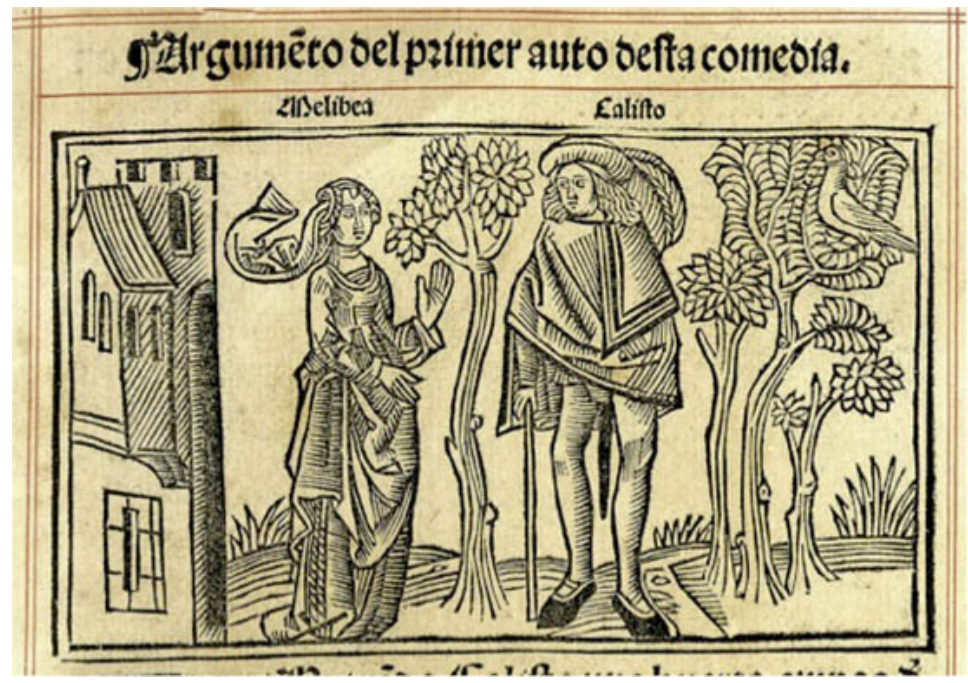

FIGURE 1. Argumento del primer auto desta comedia, Comedia de Calisto y Melibea, Burgos, Fadrique de Basilea, 1499. Signature a1. Courtesy of the Hispanic Society of America, New York.
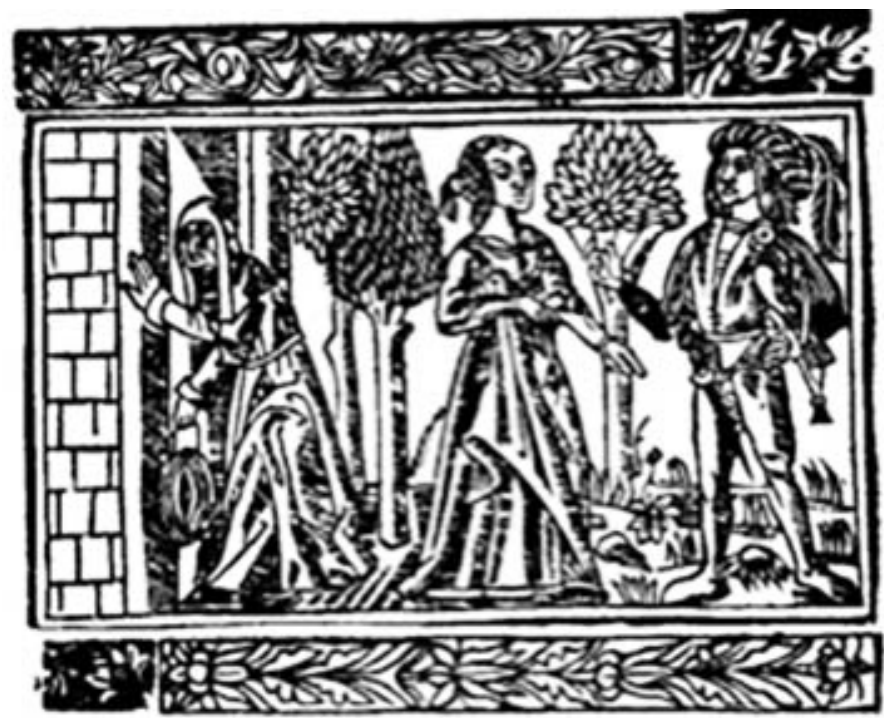

FIGURE 2. Comedia de Calisto y Melibea, Pedro Hagenbach, Toledo, 1500. Fondation Martin Bodmer, Cologny (Genève). 


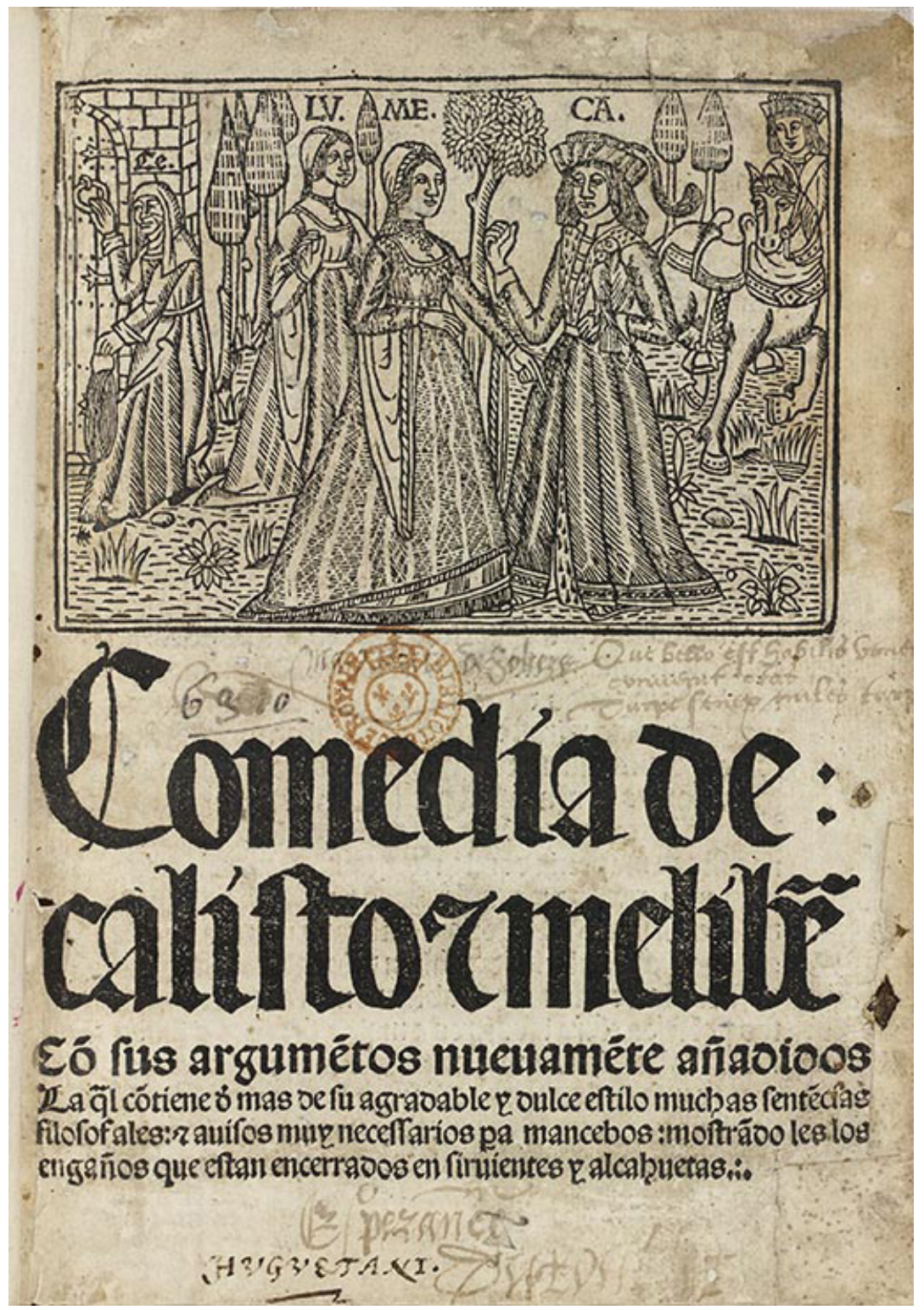

FIGURE 3. Comedia de Calisto y Melibea, Stanislao Polono, Seville, 1501. Bibliothèque nationale de France, Paris. 


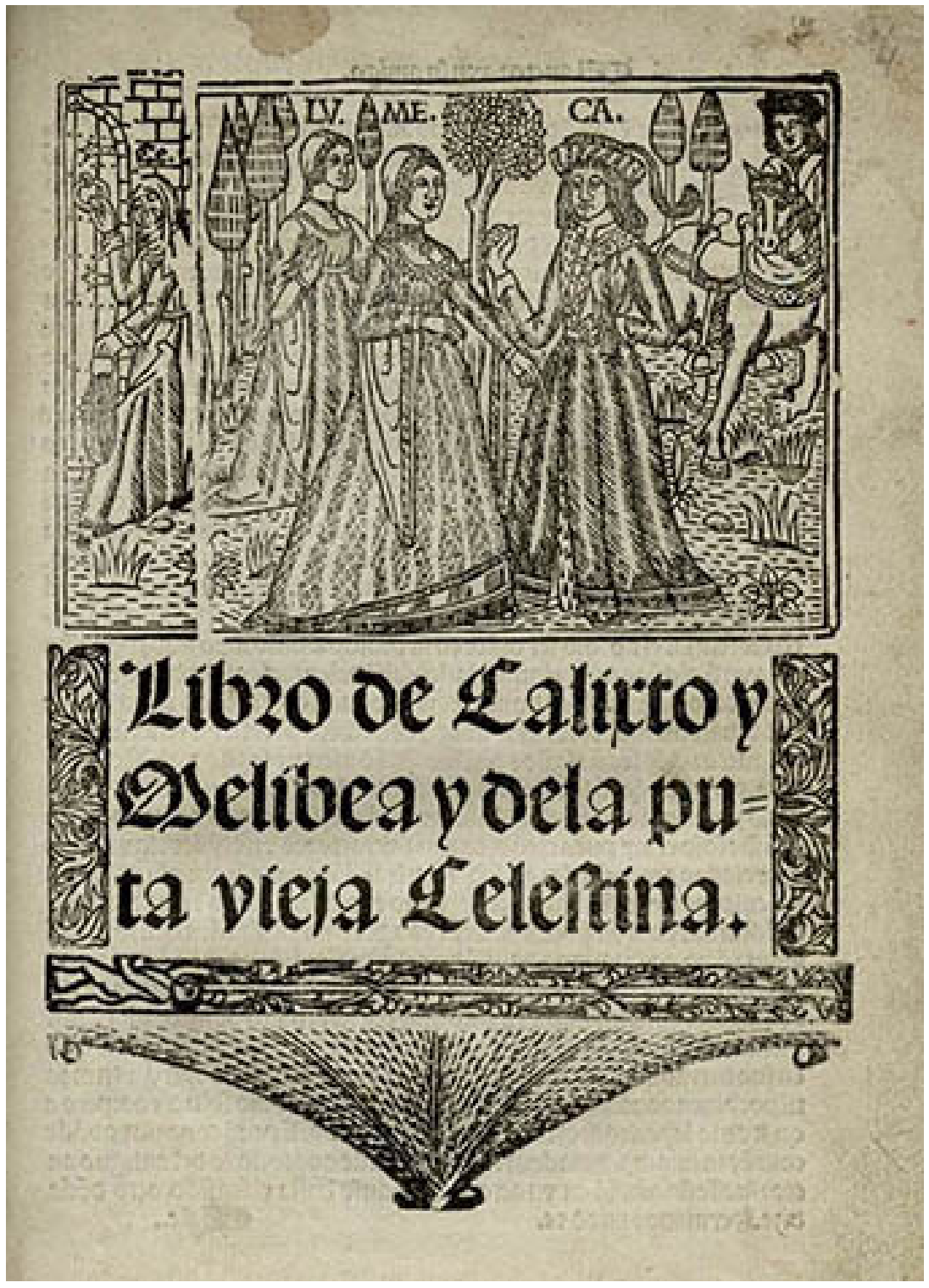

FIGURE 4. Libro de Calixto y Melibea y de la puta vieja Celestina, Jacobo Cromberger, Seville, 1518. 


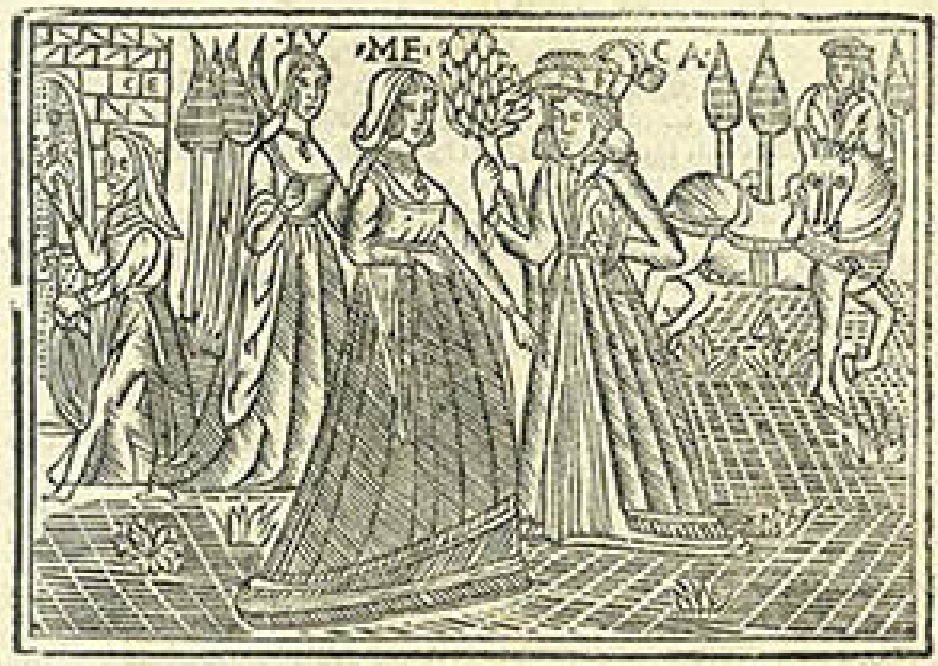

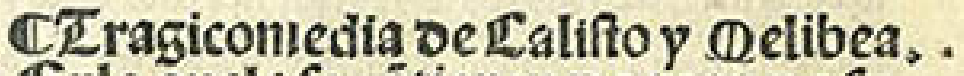
Enla quale fe cótienen oe mas oe fu agradable $\tau$ oulce eftilo mucbasfen tencias filofofales : $r$ auifos muy ne ceffarios para mancebos:moftrando les losengaños que eftá encerrados en feruientes z alcabuetas. IE nueua mente ainadido el tractado oe Eentus rio.

FIGURE 5. Tragicomedia de Calisto y Melibea, Antonio Blado for Antonio of Salamanca [?]: Rome [?], 1520. Courtesy of the Hispanic Society of America, New York. 


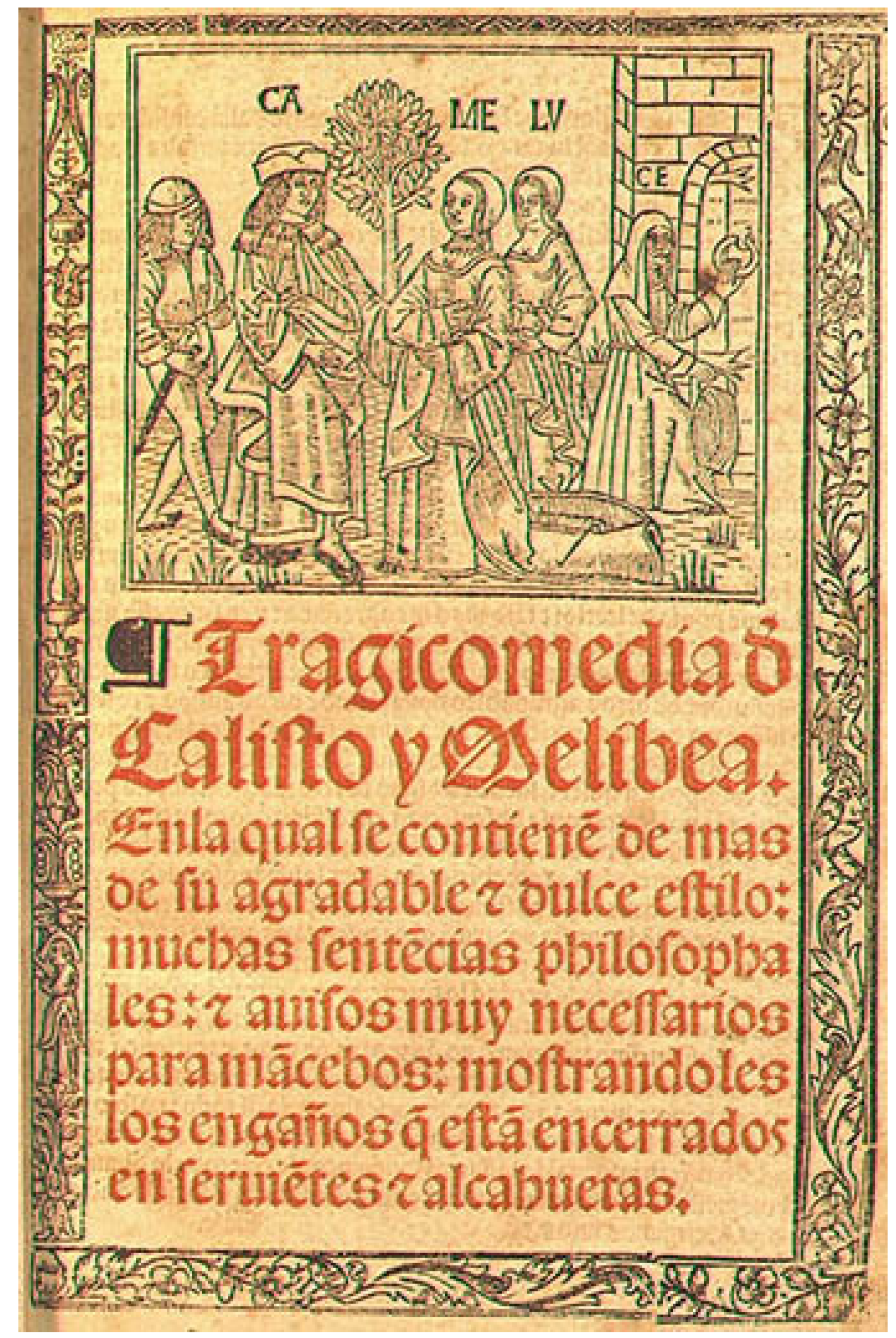

FIGURE 6. Tragicomedia de Calisto y Melibea, Juan de Junta, Burgos, 1531. Courtesy of Biblioteca de Catalunya, Barcelona. 


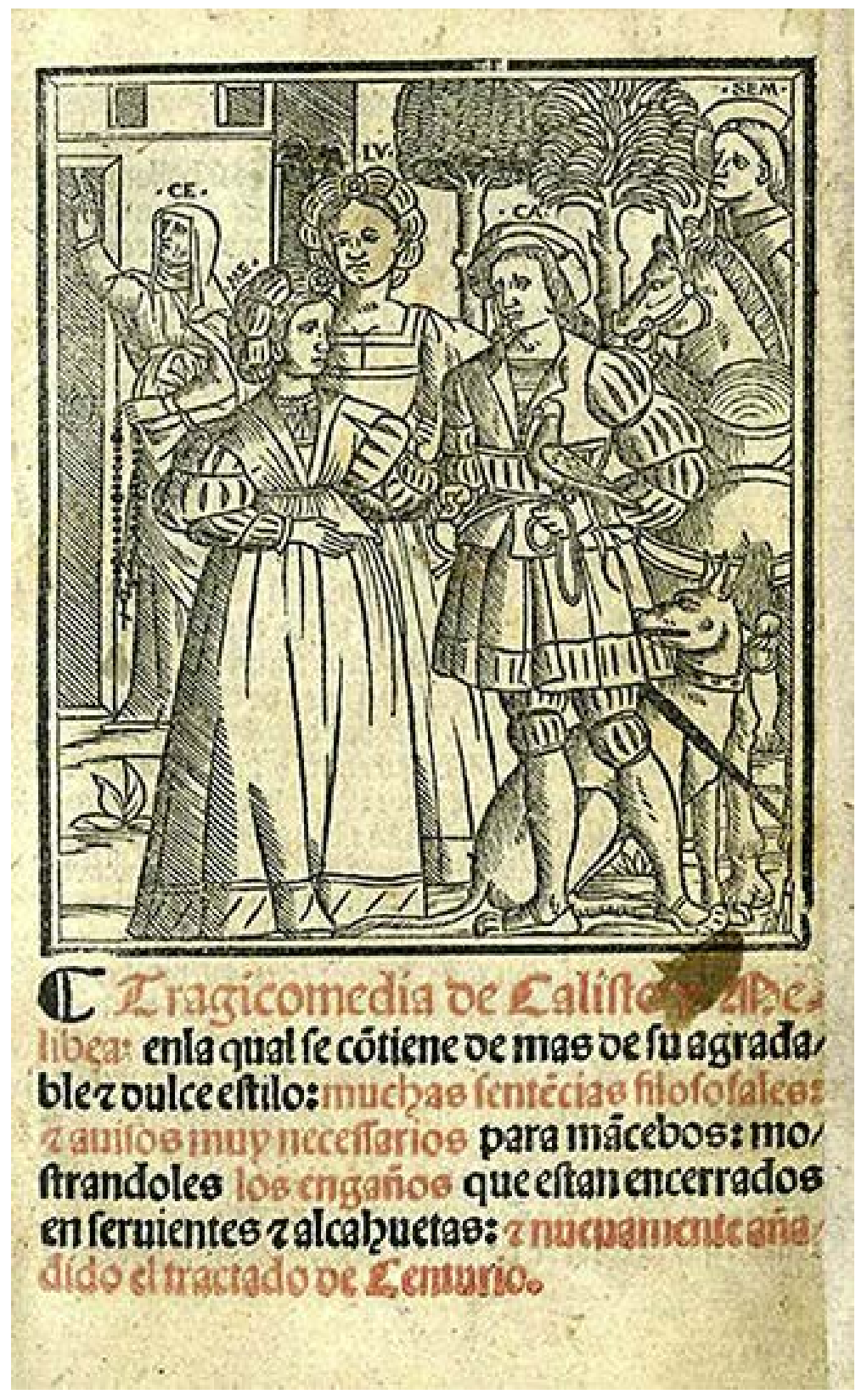

FIGURE 7. Tragicomedia de Calisto y Melibea, Juan Batista Pedrazano?, Sevilla [i.e. Venice?], 1523. Courtesy of the Hispanic Society of America, New York. 


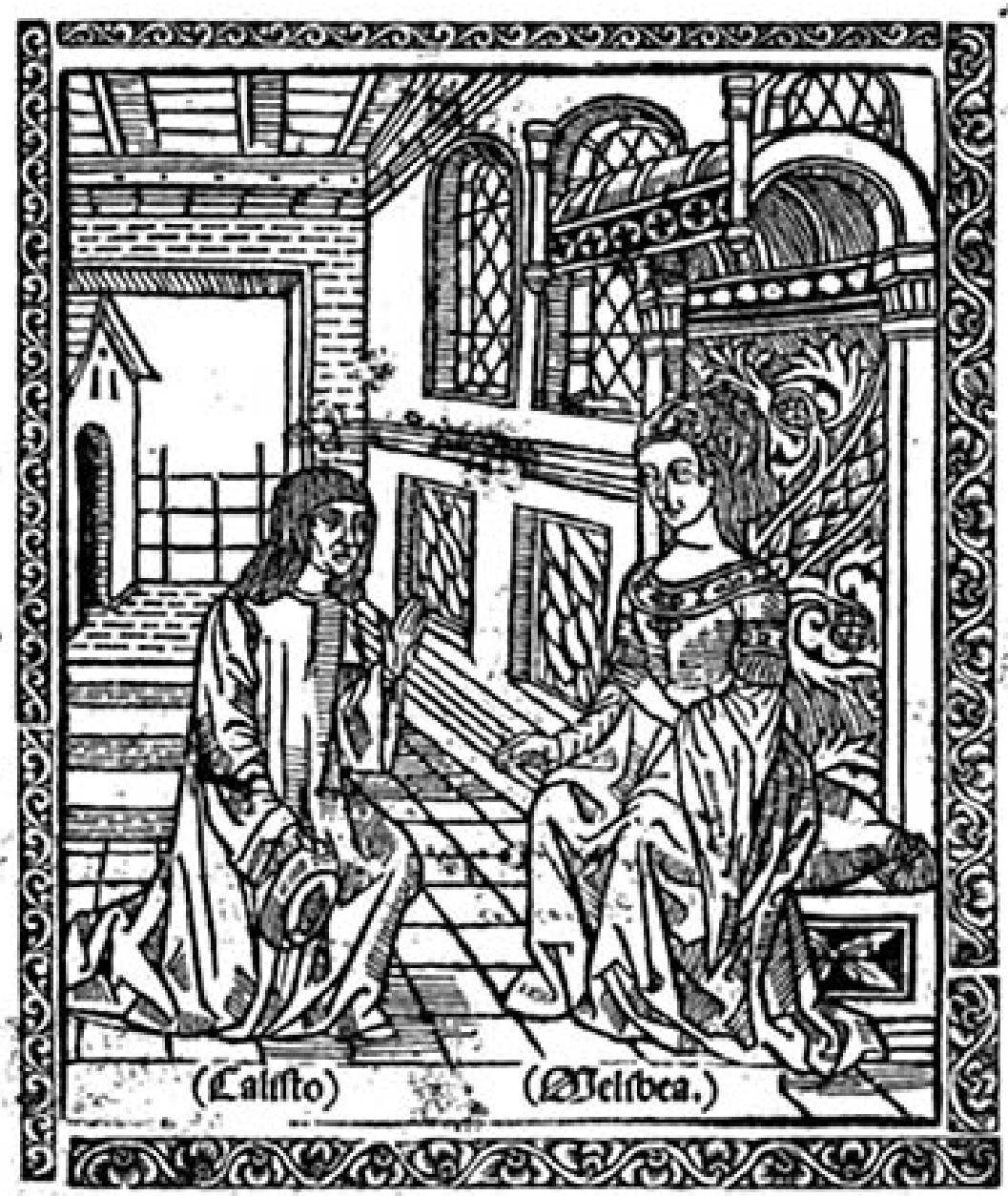

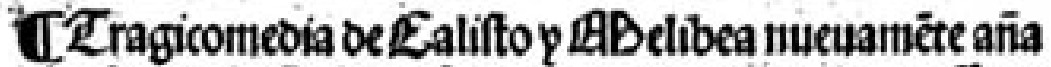
oida lo que bafta agai faltaua oe poner / enel pzocefio oe fus amozes:la qual conticte de mas oe fn agradablep oul ceftilo mudzas fentencias filofofalce: y auifos muy necers farios para mancebos: thonftrantoo les los enganios que eftan ençemaoos en feruientes y̧ alcabuetas،

FIGURE 8. Tragicomedia de Calisto y Melibea, Jorge Coci, Zaragoza, 1507. 


\section{Lelertina:}

\section{Tragicomedia oe Ealiftor}

Melibea nouamente tradocta de lingua caftigliana initalianoidioma. Aggiontoui di nouo tutto que? lochi final giorno prefentcli máchaua. Da poi ogni altra impreffione nouilfimaméte corresta: diftinets ordenada: $\$$ in pitucómoda forma reducta:adorna da etiam d' molte belliffimefigure:fegondo el nume ro di for aeti:con le perfonectiáa dietiảcti conuenic te:le qual colencllealtrcimpreffione non fi troua.

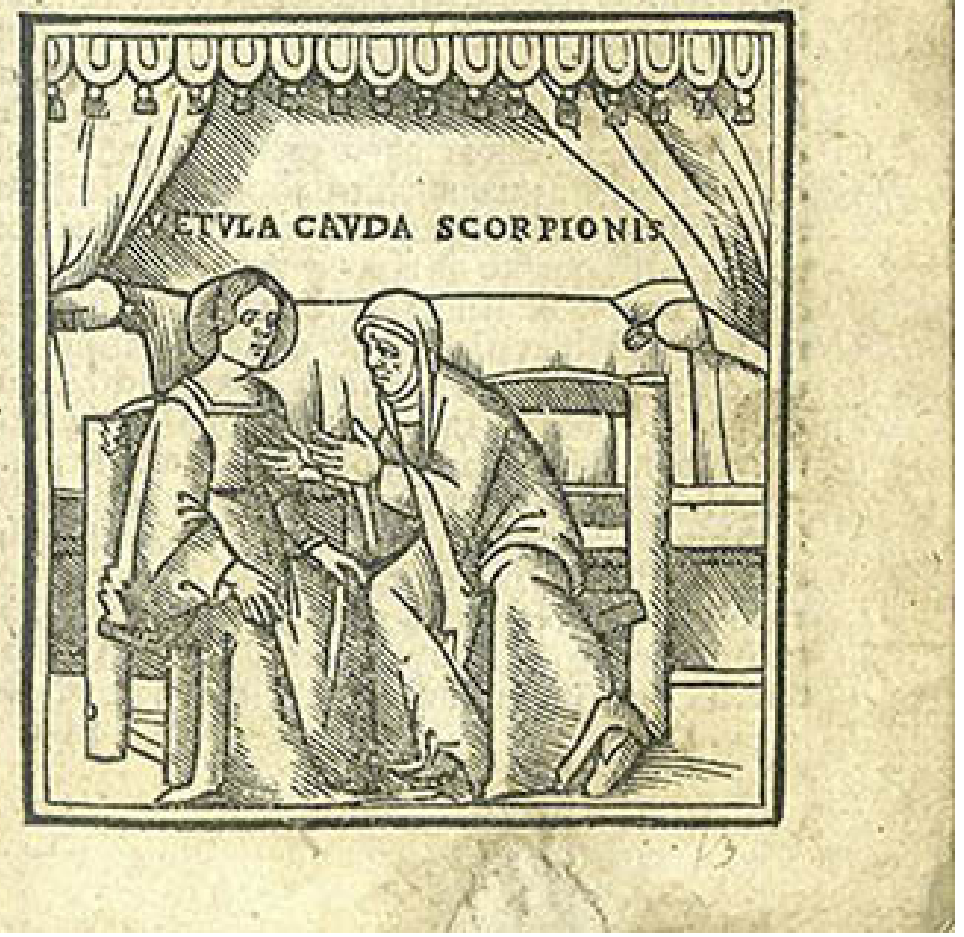

FIGURE 9. Celestina. Tragicomedia de Calisto y Melibea nouamente tradocta de lingua castellana in italiano idioma, Cesare Arrivabene, Venice, 1519. Courtesy of the Hispanic Society of America, New York. 


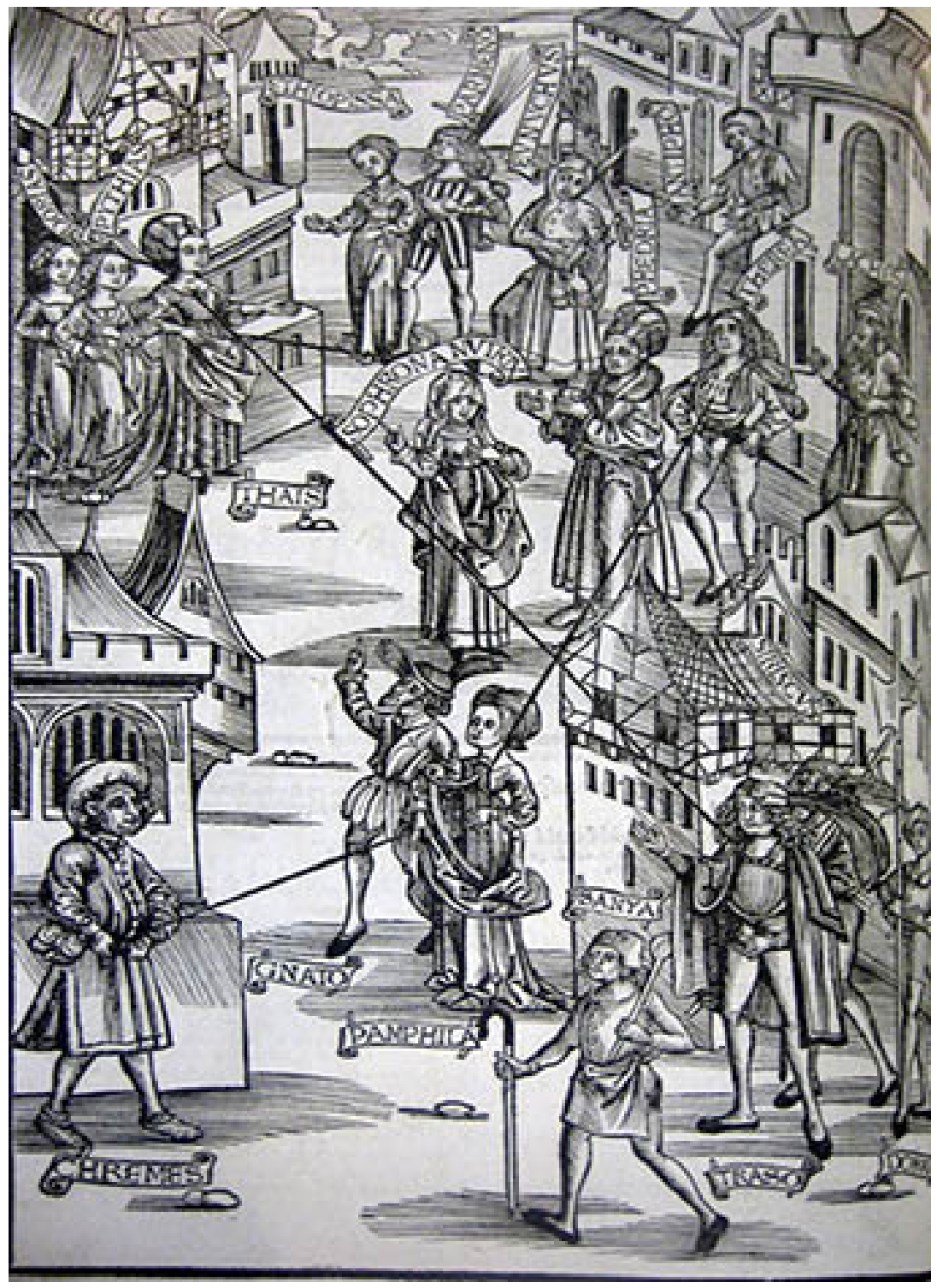

FIGURE 10. Engraving depicting the Plot of Eunuchus in Terenti[us], $\mathrm{cu}[\mathrm{m}]$ directorio vocabuloru[m], sententiaru[m], artis comice, glosa i[n]terlineali, come[n]tarijs: Donato, Guidone, Ascensio, Strassburg, Johann Reinhard Grüninger, 1496. Courtesy of Firestone Library, Princeton University. 


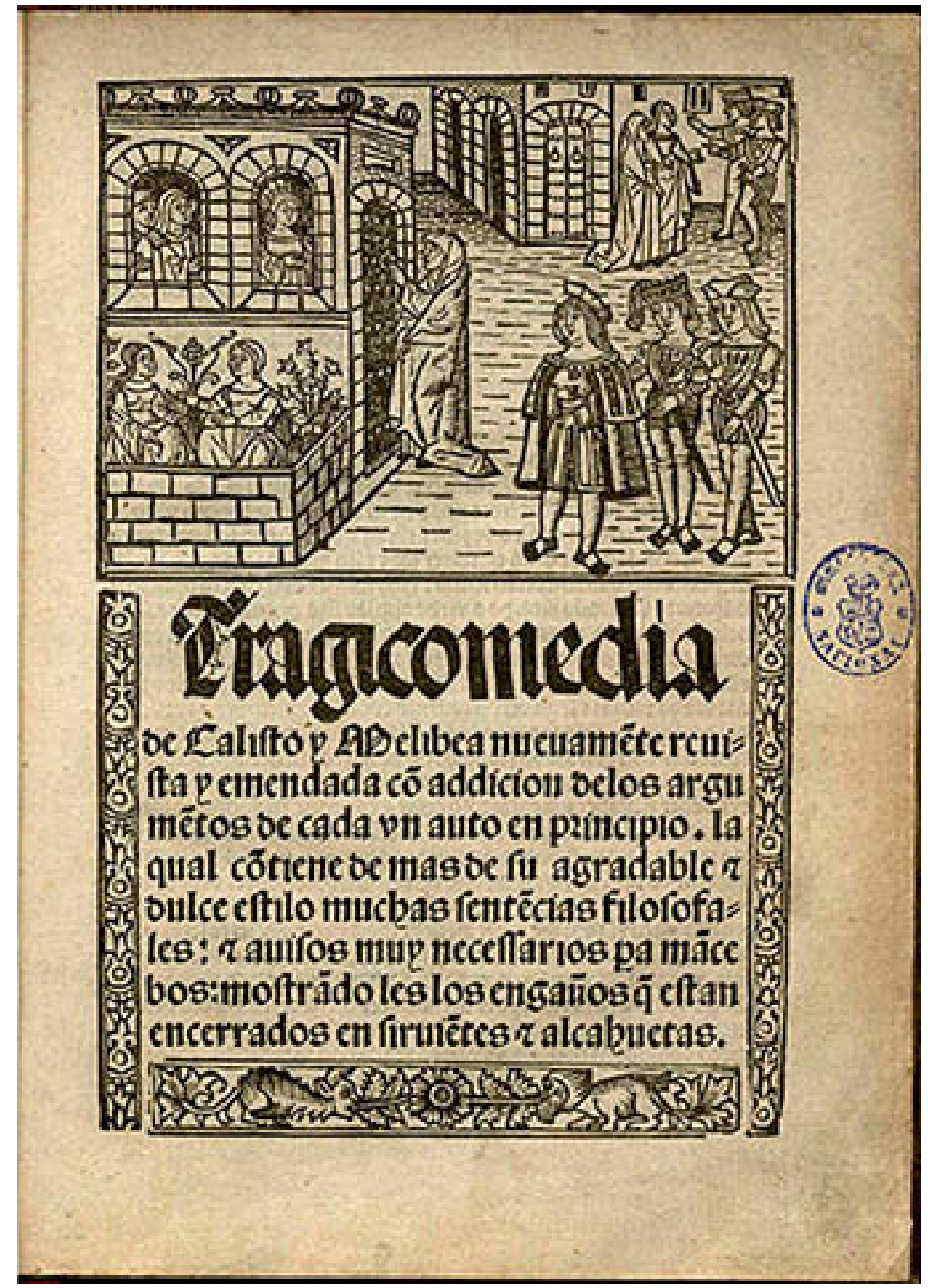

FIGURE 11. Tragicomedia de Calisto y Melibea, Juan Joffré, 1514, Valencia. 


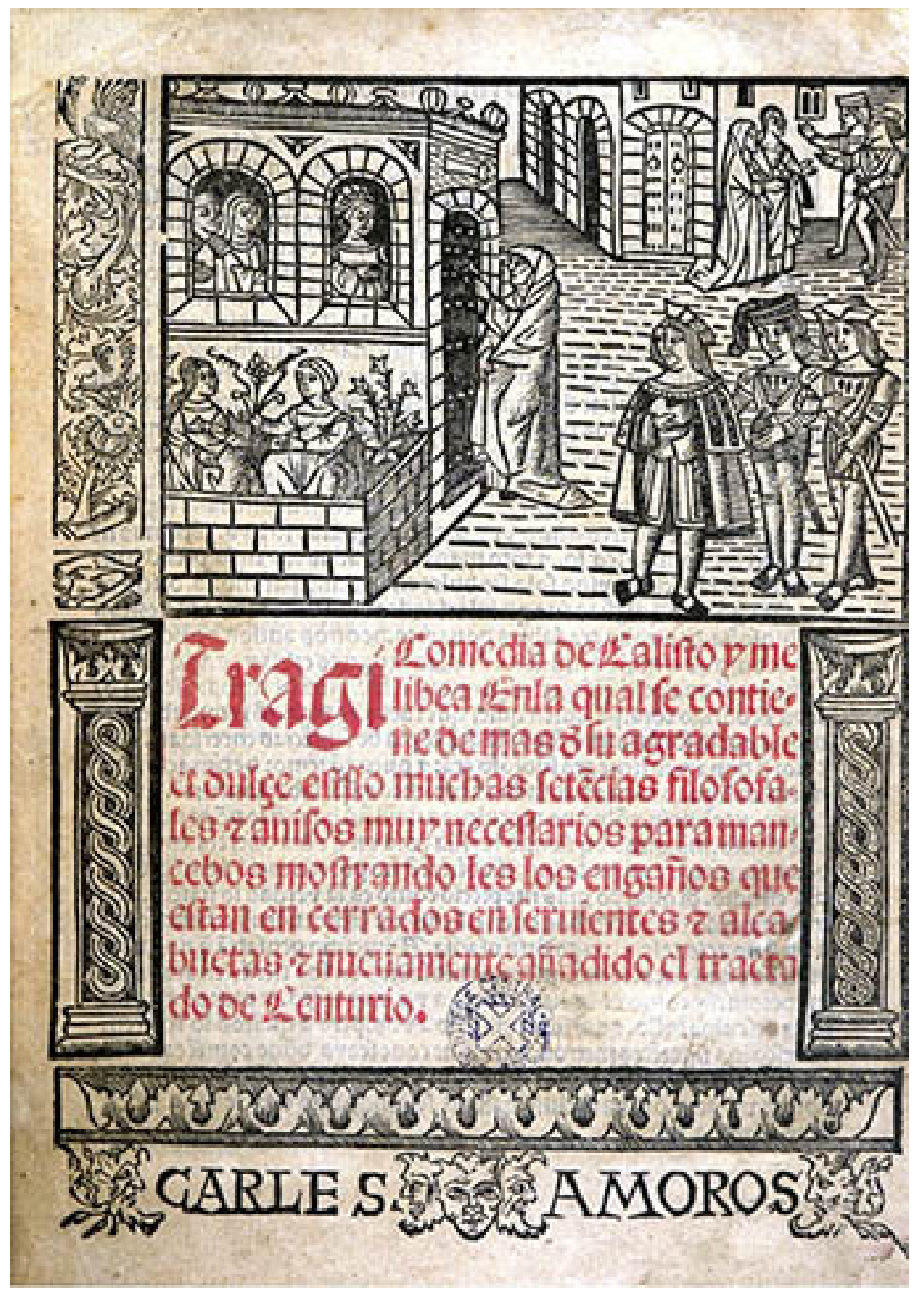

FIGURE 12. Tragicomedia de Calisto y Melibea, Carles Amoros, Barcelona, 1525. 


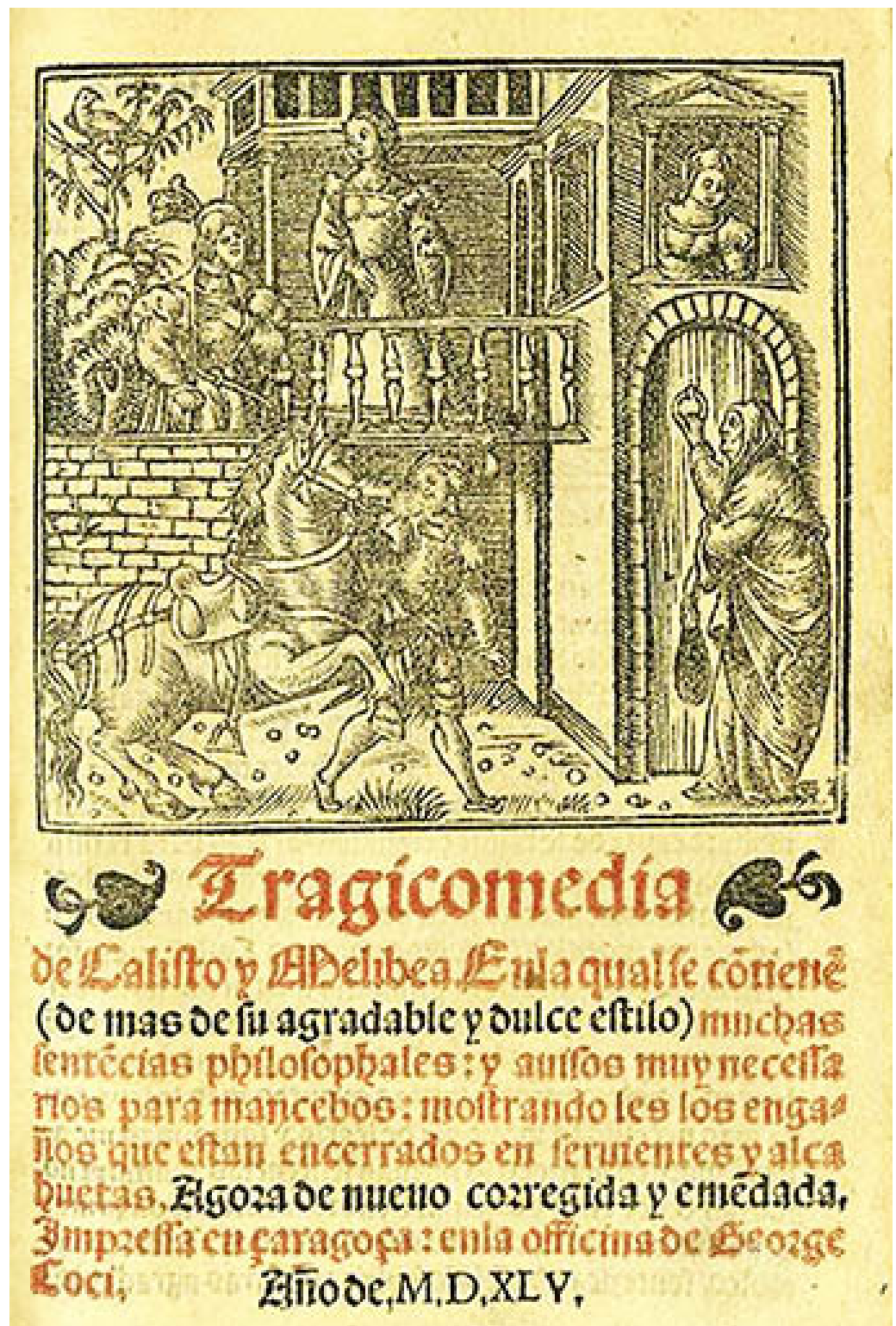

FIGURE 13. Tragicomedia de Calisto y Melibea, Jorge Coci for Pedro Bernuz and Bartolomé de Nájera, Zaragoza, 1545. Courtesy of the Hispanic Society of America, New York. 


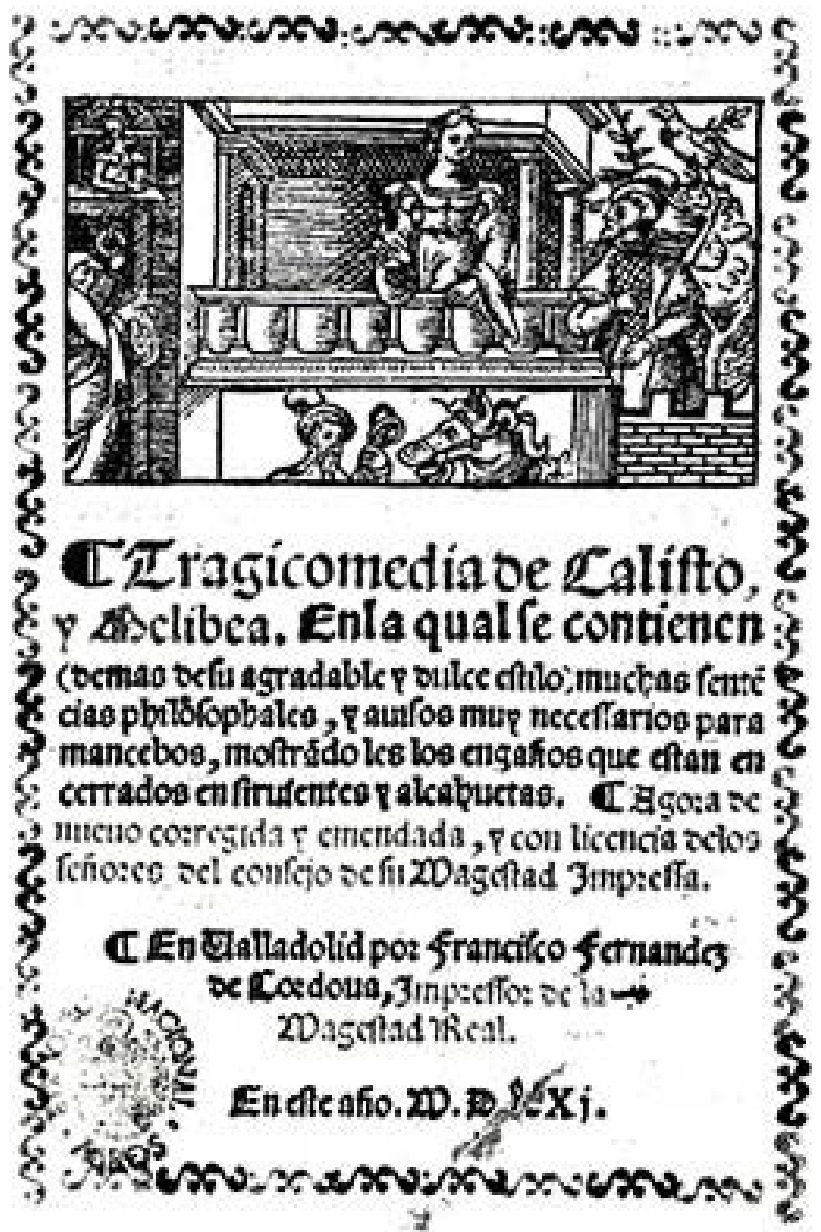

FIGURE 14. Tragicomedia de Calisto y Melibea, Francisco Fernández, Valladolid, 1561. 


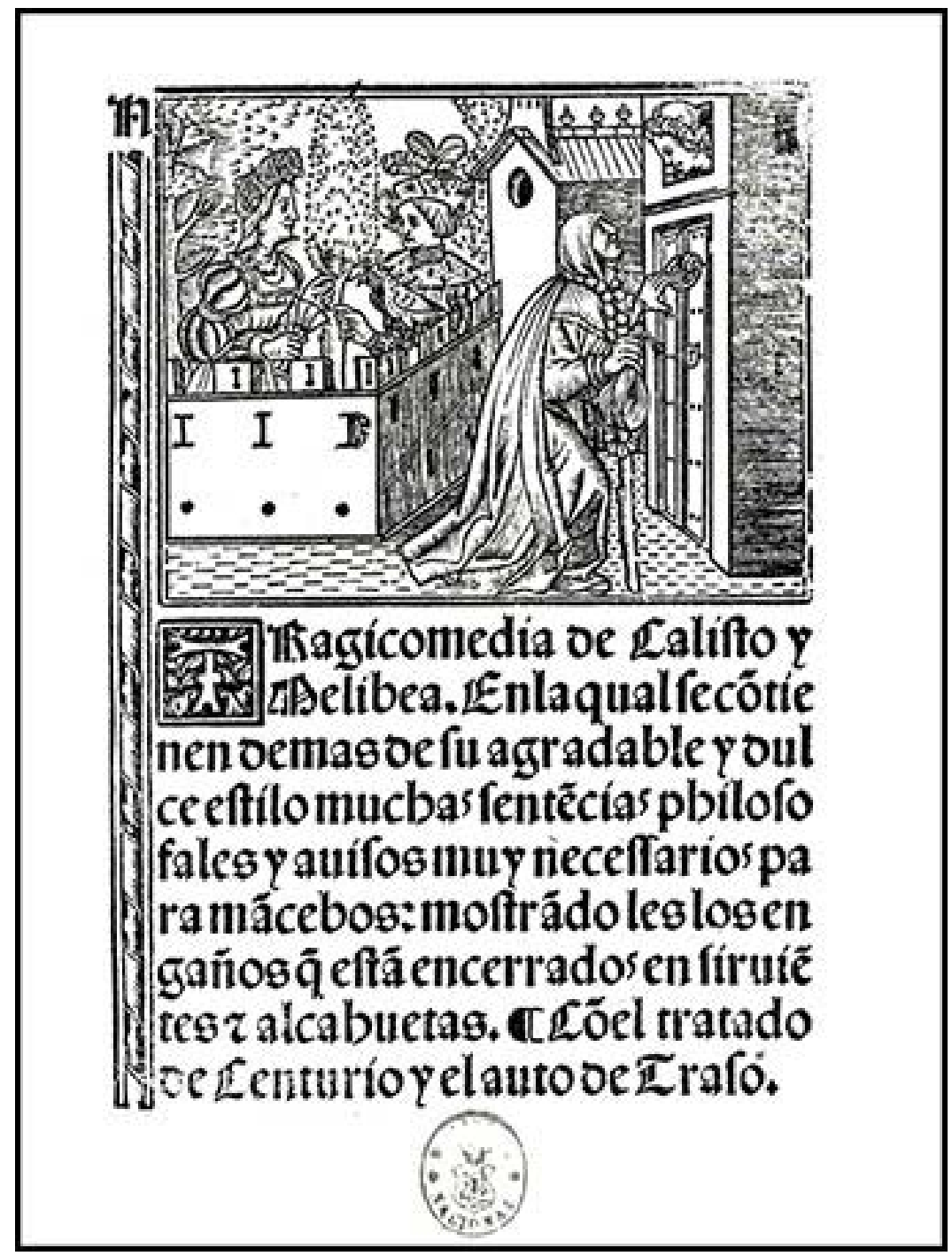

FIGURE 15. Tragicomedia de Calisto y Melibea, Juan de Ayala, Toledo, 1538. 


\section{Álbalá Pelegrín, Marta, "Gestures as a Transnational Language through Woodcuts: Celestina's Title Pages», Celestinesca 39 (2015), pp. 79-112.}

\section{RESUMEN}

Tras la publicación de la Comedia de Calisto y Melibea en 1499, La Celestina se convertiría en uno de los libros más profusamente ilustrados del siglo XVI. Este artículo analiza el lenguaje corporal y la gestualidad en las xilografías de las portadas de sus primeras ediciones, confirmando que la mayoría se integra en el marco iconográfico de la tradición teatral, orientada a la legibilidad de sus ilustraciones para ayudar a los lectores a comprender el texto. Tanto impresores como entalladores gozaban de flexibilidad al resumir el argumento o codificar emociones en la página impresa, lo que los llevaría a operar con tres programas iconográficos diferentes: el encuentro de los amantes en el huerto de Melibea, la representación de Celestina en el dormitorio de Melibea, y la condensación del argumento en un escenario teatral poblado por grupos de figuras y acciones sucesivas. En estas tres visualizaciones, los cambios en el lenguaje corporal de los personajes ofrecían diferentes lecturas de sus intenciones, sentimientos y motivaciones.

PALABRAS ClAVE: Celestina, iconografía, gestos, representación, teatro, cultura visual, portadas, ilustraciones tempranas.

\section{ABSTRACT}

Following the 1499 publication of the Comedia de Calisto y Melibea, Celestina became among the most profusely illustrated sixteenth-century books. This article analyses the body language featured in the title-page woodcuts of its early editions. Conceiving the woodcuts as belonging to a particular historical time, the study confirms that most contemporary printers conceived the work as part of a dramatic iconographic tradition and were openly concerned with the legibility of illustrations that would help readers understand the text. Printers and engravers enjoyed certain flexibility as they summarized the plot of the (tragi)comedy and codified emotions on the page, while operating under three distinctive iconographic programs: the lovers' encounter in Melibea's garden, Celestina depicted in Melibea's bedroom, and a condensation of the plot on a theatrical stage populated by groups of figures and successive actions. In these, changes in body language or the depiction of the scene convey different readings of the characters' intentions and inner feelings.

KEY WORDS: Celestina, iconography, gestures, performance, theater, visual culture, title pages, early woodcuts. 